\title{
Managing Projects in Architecture: A Study of Leadership in a Creative Industry
}

\author{
Laura Galloway ${ }^{*}$ and Amos Haniff
}

School of Management \& Languages, Heriot-Watt University, Edinburgh, EH14 4AS, UK

\begin{abstract}
The paper reports a qualitative, exploratory study of the experiences of a small sample of architects in terms of leading and managing projects. Specifically, the paper considers issues specific to architecture as creative industry and the balance architects have to achieve between the creative and business objectives of their projects. Leadership in projects is examined in the context of projects most often being understood as task-centred and the paper explores the tension between this and modern leadership theory and practice in organisations, both of which tend largely to be based on a focus on people. In particular, the paper reports findings that relate to managing and leading projects whilst maintaining conditions that are stimulating and motivating for creative workers. The study finds that there is indeed a tension between creative and business objectives in the sampled architecture firms. It finds also that modern person-centred techniques are used by architects when leading and managing projects. These can mitigate negative effects business and creative objectives might have on one another, and are observed to prompt value in projects as the autonomy and scope afforded by these techniques encourages creativity.
\end{abstract}

Keywords: Creative industries, project leadership, situational leadership, transformational leadership, architecture.

\section{INTRODUCTION}

The purpose of the current paper is to report a qualitative investigation of the project management process as led by those in architecture. The architecture industry has been selected for investigation for two reasons. First, architecture is a professional, essential service to the building industry and the starting point of most building projects. As a result, professional architects commonly find themselves leading and managing projects, sometimes in a de facto capacity and sometimes in a role clearly defined as such. The study of architects in their capacity as project leaders is limited within the extant literature, so the current paper aims to make some contribution to understanding. Second, architecture is categorised as a creative industry [1]. Project management in the creative industries is also little dealt with in the project management literature, and in fact, in the traditional Project Management paradigm of activity and outputs involving cost, time and quality, there appears little room for creativity. However, practice tells us that creative industries do operate projects, and where they do they most often comprise the application of creativity to business or commercial objectives. Architecture is one such example-in fact, commercial projects define architecture and underpin opportunities to pursue creative development in the sector.

Using case study methodology four architecture firms in a UK city were studied. Specific themes emerging from these cases include how the creative process is managed in commercial projects, how commercial projects are led and managed by architects as creative workers, and how

*Address correspondence to this author at the School of Management \& Languages, Heriot-Watt University, Edinburgh, EH14 4AS, UK;

Tel: +44(0)131451 8286; E-mail: 1.galloway@hw.ac.uk architects balance the creative and commercial goals of their firms.

The paper starts with a summary of the literature on project management and leadership. It goes on to discuss the issues associated with project management in the specific context of creative industries. Issues emerging from the literature are summarised and these are followed by a description of the methodology employed to address them. Findings from the research are provided thereafter, as is a discussion and a conclusion, including the identification of opportunities for further research.

\section{PROJECT MANAGEMENT}

The Project Management Institute provides a simple and widely used definition of projects: 'A project is a temporary endeavour undertaken to create a unique product, service or result' [2]. A project has a temporary and unique character and this differentiates project work from routine work [3]. The objectives of projects are most often defined as time, cost and quality/specification; the 'Project Management Triangle' or 'Iron Triangle' [4-7]. This 'Project Management Triangle' has been the basis of understanding projects for decades and has informed scholars and practitioners alike. From both, development of tools and techniques to manage projects has occurred, and much empirical study based on the three pillars of Project Management has been undertaken. However, more recently, the traditional paradigm has been criticised for its limitations. For example, writers such as Briner, Hastings and Geddes [8], Pinto [9] and Kerzner [10] have criticised the 'triangle' conceptualisation for not allowing the connection with strategic orientation or focus. Since projects have been perceived as discrete units of activity, the need to relate them directly to an organisation's 
greater strategy or goals is absent. Evidence of experience tells us this is not the optimal means by which value can be extracted from projects. Researches of Thompson [11], Shenhar, Dvir, Levy and Amaltz [12] and Wald [13] have found projects to be a highly effective means by which organisational strategy is operationalized, and that this is best achieved when projects' alignment to strategy is clear, particularly to those leading the project. Certainly, Velcu [14] claims that strategically aligned projects have a higher probability of meeting time and budget objectives. These developments in understanding the value-adding potentials of project management have given rise to the conceptualisation of Strategic Project Management, which embeds strategic aims and activities within projects [15]. From there, other developments in theory and practice in project management and leadership have emerged. One such development involves consideration of how best to lead teams within projects, so that team members perform optimally, stay motivated and invested in the project and associated strategic organisational goals. Again, the traditional Project Management 'triangle' does not provide much insight for those who lead projects, and as a result Shenhar [16] refers to 'strategic project leadership' as that which aligns leadership style to achieving strategic goals. While projects have traditionally been conceptualised as task-oriented, strategic project management and leadership allow for person-orientation; in order to achieve strategic objectives, project leaders must engage with behaviours and activities that communicate, motivate and engage those working in the project. These are all principles of modern person-based leadership styles, and particularly transformational leadership. This is discussed in the next section.

\section{LEADERSHIP OF PEOPLE}

Throughout the business and leadership literature, theories on leadership appropriate for the development of value is most often person-centred. This is based on the premise that in order to achieve best development and best value from people, a leader must understand what drives and motivates followers, and encourage development of them commensurate with the development of the aims of the organisation. Since not all people are of the same skills, have the same motivations, or indeed, have the same aims or agendas, some flexibility of leadership style, contingent on follower 'maturity' [17] is required to extract best value from groups. This is the underpinning theme of Situational Leadership [18].

Building on the flexibility inherent in situational leadership, in terms of extracting effort and performance from people, transformational leadership is often cited also. The two main premises upon which transformational leadership is based are that the leader must demonstrate vision, attitudes and behaviours that influence follower behaviour, and that leaders much have individualised consideration of followers [19]. So, according to transformational leadership theory, the conduct of the leader is critical, as is engagement with followers as individuals to understand their needs and aspirations. This promotes the idea that followers are valued as individuals and that their ideas and actions are important. The more valued followers feel, the more they are supported and encouraged, the more autonomously they will engage with the aims of the organisation [20]. This is discussed throughout the leadership and business literatures as important to organisations as it affords optimal conditions for highly skilled workers who seek respect and autonomy and in turn can apply these in the form of innovation or other valueadding [21]. In fact, both situational leadership and transformational leadership theories have informed much practice in most types of organisation studies [22, 23]. The notable exception is within the project context where, other that exceptions such as Shenhar [24] and Kaulio [25] for example, person-based leadership is little addressed. Another area largely excluded from project management research is the leadership and management of projects in the creative industries and it is to this topic that we now turn.

\section{PROJECT MANAGEMENT AND LEADERSHIP IN CREATIVE INDUSTRIES}

The literature that deals with project management in creative industries is limited. As discussed above, the traditional view of project management is that it is taskoriented and as a result there is no scope in which to conceptualise how creativity might contribute, or how it might be managed or even fostered in projects. New developments towards conceptualisations of Strategic Project Management are helpful though, as in affording scope to consider person-based management within the project management paradigm, they also can by extension allow for intellectual development of conceptualisations of creative-person management specifically, with all the itinerant qualities, issues and opportunities that occur or may be realised.

Mumford et al. [26] discuss the management of people in creative industries and the issues associated with managing effectively the opportunities creative workers embody in term of innovation and value to an organisation. Hotho and Champion [27] discuss the 'inadequacy of conventional management approaches' for releasing creative knowledge and abilities. Traditional management, like project management, tends to focus on task-based activity, temporal exchange of activity from employees to perform specific tasks or functions, for which they receive financial return. More modern thinking on leadership and management has identified the use of personal development and engagement amongst staff to add value as noted above, but with creative workers in particular, much knowledge is tacit, not time bound, and not readily and easily linked to function. However, as Townley, Beech, and McKinlay [28] point out, creativity must function within the structures of the socioeconomic environment if it is to have value ascribed to it, aesthetic or economic, and in turn, add value to that environment. They go on to say:

"Concerns are that marketization and the imperatives of the commodity form fundamentally change cultural products, cultural producers and cultural labour, constituting yet further accretion of business and management into cultural life .... As the discourse and practices of business and markets take hold, concerns are that the 
nonmonetary value of 'culture' and 'art' is lost. Such debates underpin analyses posed in terms of contrasting logics, where the aesthetic is pitted against the efficient, commerce battles with a creative logic, and 'art for arts sake' competes against the exigencies of commercial appropriation" (p.940).

Architecture is no exception to this dualism.

Person-based leadership and management, as discussed above, has a role to play in affording scope for creativity. Within this, autonomy is identified as a key element in the management of people in so far as it affords them a sense of control over their professional activities and freedom to think creatively in terms of task completion and problem solving [29]. This is even more pertinent in creative industries [30, 31]: intuitively, we know that micro-management of tasks and time of creative individuals will inevitably be counterproductive.

Despite these, creative industries are still industries and as such must fit some reasonable business model if they are to be sustainable. Therein lies the balance leaders in creative industries have to manage on a daily basis. In the highly project-based construction industry these considerations have to apply in projects. The various person-based leadership and management styles that foster engagement and buy-in in staff have to be afforded in projects also. Kaulio [32] identifies a need to study transformational leadership and management in projects based on the relative absence of these in the extant literature. We would contend that this is worse in the literature on projects in creative industries. The current paper therefore seeks to offer a contribution to our understanding of these issues by providing some initial inspection of the processes and practices in the highly project-based architecture sector. Specific themes to be explored are:

1. What are the experiences of the architects participating in the current study in terms of developing projects creatively?

2. How do architects balance their creative and business objectives?

3. What are the experiences of the architects in terms of managing project teams?

\section{METHODOLOGY}

To explore the issues identified, a case study methodology was employed. Qualitative research was considered the most appropriate because leadership, management and creativity are all human behaviours and as such are best understood by investigating the perspectives of the people involved [33]. Also, since there is little research on the experiences of leading and managing projects in creative industries, qualitative research allows for unanticipated themes to emerge by affording a flexibility of response from participants and a depth of understanding from those whose experience we seek to understand and analyse $[34,35]$. Case studies, in particular, are very useful as the limited number of subjects studied allows for a depth of investigation of each and this affords a depth of insight not easily captured by other means [36]. The small number of cases was a deliberate attempt to capture the stories of the participants in the research, from which the unique perspectives of leading and managing creative people in the project context might emerge. Following Yin [37], data on each case was captured by various means to afford some triangulation, including interviews, engagement with published materials about each firm, including those presented by the firm-such as marketing materials and websites - and public company data.

The four cases included in the study were selected specifically to have the small sample as homogenous as possible. All the firms had been trading for more than ten years and all were located in the same UK city. Each firm was privately owned and was defined as per the European Commission [38] as a small firm-ie., each had between 10 and 49 employees. A senior partner in each firm was interviewed. Interviews included few structured questions; the interview guide asked broadly what interviewees' experiences of leading projects in architecture were and how the creative process is managed. The lack of prescription was intended to afford conversation and rapport and allow themes to emerge during the interview process rather than restrict conversation to pre-identified (and potentially preemptive) issues. The only 'closed' question asked was "do you consider the firm's primary focus is creative or commercial?" A summary of the cases is given in Table $\mathbf{1 .}$

Table 1. The cases.

\begin{tabular}{|c|c|}
\hline Case & Focus of the Firm as Identified by the Senior Partner(s) \\
\hline \hline A & Creative \\
\hline B & Creative \\
\hline C & Business \\
\hline D & Creative \\
\hline
\end{tabular}

Each of the four firms do a variety of architectural work, but as Table 1 illustrates, interviewees for each case identified the firm as primarily strategically focused on either creative or business objectives. All architectures require creativity. We contend the degree of it varies though, and can be conceptualised on a continuum ranging from highly creative, such as new municipal buildings or modifications to historic buildings, through to the development of schools and libraries, retail premises and otherwise urban environment, to more routine domestic home building or developing.

Each interview was recorded and transcribed. As per established practice for qualitative studies [39] analysis was conducted by each researcher reading the transcripts and identifying themes independently and upon collaboration consensus was achieved.

\section{RESULTS}

What are the Experiences of the Architects Participating in the Current Study in Terms of Developing Projects Creatively?

All of the interview participants spoke at length about the creative process of architecture. All of them mentioned that 
they have to engage and lead the client, and that this is the most important part of the process of creating a building that will meet the functional and aesthetic objectives of each. There are various stages to this. All interviewees identified the need to develop a strong relationship with clients and the need for trust to be established. This allows them to lead the client more efficiently as clients must have faith in the architect's professional knowledge of both engineering and trust in his/her creative judgement. Interviewee $\mathrm{C}$ explains,

"its about personal contact, its about individuals getting on... if you don't hit it off with the client on a personal level that can only work for so long. Its about winning that trust and maintaining that trust and not letting them down".

In this sense a large part of the architect's role is to lead the client in the creative process. Case A respondent put it thus:

"a good architect has to be somebody that can be fairly strong. Strong but caring, sensitive you know, because if you just do everything that the client wants then you'll never produce good architecture".

Similarly, Architect B mentions "its not unusual for there to be a lot of second guessing" and Architect A says of domestic clients specifically:

"they are not used to organising buildings... sometimes very nice people but just got some crazy ideas and no idea about budget cost and time and whatever, and constantly phoning up every day with a new idea".

The inference is that management and leadership in the client relationship are essential parts of the creative process in architecture. In fact, all the architects claimed that from the establishment of trust, the development of designs and plans for buildings may follow. As Architect C puts it,

"you need to establish what they're [the client] looking for in the project...you do sketches and try to get a feel for the type of project, the type of building space that the client has asked for and you go round in circles, you know, you figure it out. It can be quite interesting”.

Thus the design of buildings is a creative and iterative process requiring leadership from the architect and trust and communication from the client. From this starting point, most of the interviewees expressed that the building design is a creative and rewarding process. For example, Respondent C claims:

"the relationship between you and your client, how you manage the creative process in terms of leading to what you eventually produce for them in the buildings .... we like to think for the large part its ourselves...but its about trying to tease out from the client what they're after and why. So that - whether they know it or not - they're playing a part in the creative process".
This notion of creative partnership with the client is mirrored in the comments of Architect B:

"I'm listening to the client and what their interests are and those things can come together. And I always want the way our buildings look to be a surprise to me as much as our client...its nice to think that if there's a fertile discussion it should surprise us as well as the client".

On the other hand, all architects expressed some frustration at the various ways in which creativity can be stifled. In Case A, identified in Table $\mathbf{1}$ as design-focused, the interviewee expressed frustration at the focus of some of his commercial clients, where the creation of a building is for a pre-planned, pre-budgeted building for a specific function.

"Its obviously a subjective area, but our clients would generally put things like programme and cost above aesthetics, and we would always put aesthetics number one".

Myriad regulations were also cited by respondents as working against creativity. All the architects agreed with the general principles of, for example, UK Building Standards regulations, accessibility issues borne of Equality legislation, and Health and Safety regulations. However, there was a general sense that cumulatively they act to stifle creativity. Respondent D puts it thus:

"You want to create something and you're just
constricted by rules and tick boxes... You've
got Building Standards which you have to
comply with, but people want you to comply
with other things as well, for example, aimed
at accessibility... Because of the threat of
prosecution, these are straightjackets".

Another issue identified as a stifler of creativity, surprisingly, was strong design associated with the brand. Rather than encourage creativity amongst architectural staff, a firm's signature style was often associated with restriction for individuals. This relates to leadership amongst employees in architecture firms. Participant A explains:

"Well XXXX[other architecture firm] he's had
very strong people underneath him, who were
brilliant designers. Now he's lost a few of
those and his style has weakened because a lot
of the time these guys don't get the limelight...
If someone is controlling all the design, there's
a general sense of frustration I think... It is
demotivational for people who want to have a
style in their careers, you know... Even if
you've got a great boss and whatever, yeah,
there's a demotivating aspect to that".

So a further issue in terms of fostering creativity and managing creative people and processes involves having a solid reputation for quality and design, but not directing too restrictively how that is interpreted and to allow staff to develop. Again, this points to the need for architecture firms to achieve a careful balance in terms of leading other architects and leading architecture projects. 


\section{How Do Architects Balance their Creative and Business Objectives?}

While maintaining that his firm has a creative focus rather than a business one, the respondent from Case D admits that more routine contracts involving less creativity are required for the pragmatic reason of commercial survival. Conversely, interviewees from cases $\mathrm{A}$ and $\mathrm{B}$ (who also claimed that their firm's strategic focus is creative) also do routine work, but they maintain their priority remains the aesthetic. The Case B respondent added that a creative focus in itself underpins the business case:

"we are here to make good buildings and I believe if you do that you should make money...that's our trade, that's our craft, that's what we have to do first and if we don't get that right we're not going to make money".

Case $\mathrm{C}$ was the only one in which the participant admitted that the strategic focus has been business-oriented as opposed to design-oriented. However, the senior partner in Case $\mathrm{C}$, expresses some concerns about the strategic focus having become too business oriented at the expense of more creative work. He notes that routine, pre-budgeted, prescriptive projects "are a relatively safe haven at times like this [ie. recession]". However, he also goes on to express some regrets about this:

"we've been too successful in terms of the retail work that we're doing, the repeat business clients. We've neglected the professional profile, our design credentials, so that's actually something we're trying to redress".

Again, the management of architecture practices seems to require a balance of business objectives with creative concerns and there is some evidence that the ideal situation for architects is when the former affords scope to the latter, and where creativity forms the basis of successful business outcomes.

\section{What are the Experiences of the Architects in Terms of Managing Project Teams?}

According to the participants in this research, the project team in architecture includes the clients. Otherwise, project teams include for the participants in this study, the architectural and technical staff in the firm. The leadership and management of these staff appear to be person-based, in that participants in the study identified various stylistic features most often associated with person-based or transformational leadership. For example, Respondent C claims:

\section{"you have to keep investing in people who work on it [a project]... There are a whole host of influences on whether staff are settled and happy...that you've got the right type of project, that its of interest to them, whether it's the type of work they're happy being involved in"}

Pertinently, Participant B identifies that to keep staff engaged and working creatively in a 'crafts based design organisation' it is important to acknowledge that "the standard capitalist models don't necessarily work well”.

Project teams are not restricted to the architecture firm, however. As well, in many cases, there are a host of other stakeholders. For example, Participant A identifies a project might involve "landscape architects, structural engineers, mechanical and electrical engineers, planning supervisor, lighting consultant, acoustic consultant, infrastructure engineers or civil engineers, interior designers...". Some of these people may work within the firm, whole others will work for other firms or be contractors. Other stakeholders include also those involved with planning and building regulations from local authorities etc. Where an architect leads a project, all these stakeholders must be brought within the parameters of the project and managed and led in order to achieve timely, quality outcomes, within budget. But as a creative process, scope and space for creativity and design must be afforded also. The challenge is achieving these multiple aims. Sometimes this goes well, and inevitably, sometimes it does not. Architect A expands:

"Some of them just fall into line and they know
you are the lead consultant and they just do
what they're supposed to do, and they know
the client is watching and so everything goes
fine. But yeah, sometimes you do get certain
egos which are trying to break out."

Respondent B expresses similar frustration with project teams sometimes being made up of disparate groups, often with different agendas:

"you can't be the old autocratic sort of architect with a wee bow tie who everyone fawns over. All that's gone and I'm very glad its gone, but it also doesn't mean that architecture is somehow produced by committee. That's another enormous mistake that is made today...there are all these interest groups all wanting boxes to be ticked"

Within this milieu the project must progress. The interviewee from Case B explains how leadership and management of the project are the basis for getting it completed for the client:

"you have leadership... and that gives you a
better chance of success. And that's what we
tell the clients as well. We try and say to the
clients if you come to us there may be a little
difficulty and difficult argument, but it will be
based on us trying to lead your project for you
and not just letting everyone else out there
design it and push it in whatever direction'. So
it's a question of leadership."

So the study provides evidence that the management of architecture-based projects involves leading teams that are made up of eclectic groups and individuals, some in-firm, others external. To a large extent the client is also a team member in that they must be fully consulted on the practical and creative deliverables. The testimonies of the architects in the current study suggest that management and leadership are flexible and personal and balance of myriad interest becomes an essential skill for successful completion. 


\section{DISCUSSION}

The literature identifies that the management of creative workers requires skills and organisational structures that are different from traditional ways of managing people [40]. The current study suggests that this is borne out in the architecture sector and in the project context. Similarly, in the context of balancing creative and commercial interests, a specific issue in creative industries, the current study finds that architects exercise much balancing of interests and flexibility so that the commercial interests of the firm can be developed through and not instead of creative work. From a leadership theory perspective there appears to be evidence of situational leadership in that flexibility is a found to be a requirement of successful leadership in architecture projects primarily because of the various, and often several, stakeholders involved. The architect as a leader must adapt his/her leadership style to suit the agenda or expertise (maturity) of each and respondents identify this as a feature of successful architecture project management. Concurrently, there is much evidence in the study of the use of transformational leadership techniques. The two key features of transformational leadership, inspiring conduct and individualised consideration of individuals, are demonstrably used by participants in this study to foster follower engagement. They appear further to afford the support and intellectual and design autonomy critical to allowing creativity to develop amongst followers and to feature as a commercial application and advantage for firms. Certainly Hatho and Champion's [41] contention that 'such activities enhance organisations' capability to remain responsive to arising opportunities' (p.34) seems to apply to architecture as a creative industry sector, and are not diminished by their application in projects.

\section{CONCLUSION}

The current study is limited in that it focuses exclusively on one professional sector in the construction industry, using few cases. While the low number and strict focus was intentional for the purposes of affording a depth of exploration, it would be interesting to follow-up with a larger, broader investigation of the architecture sector, and indeed, other parts of the construction industry. Similarly, further in-depth studies, like the current one, in different creative sectors would be interesting in terms of contributing further to our understanding of how management and leadership of creative workers are conducted in order to afford outputs that meet both financial and aesthetic objectives. The contribution of the current paper lies in its first steps in terms of exploring the process involved in managing projects in one creative industry. Other creative industries are similarly project-based of course. We argue there is an important research agenda currently underexplored in terms of the disconnect between research into project management as paradigmatically understood as taskoriented, and research into managing people, especially creative people and the creative processes that they undertake in the context of creative projects.

\section{CONFLICT OF INTEREST}

The authors confirm that this article content has no conflict of interest.

\section{ACKNOWLEDGEMENTS}

Declared none.

\section{REFERENCES}

[1] Scheffel E, Thomas A. Employment and intangible spending in the UK's creative industries: A view from the micro data. In Economic \& Labour Market Review. London, Office for National Statistics 2011.

[2] PMI. A guide to the project management body of knowledge : PMBOK guide/Project Management Institute. Project Management Institute 2004; p.5

[3] Larson EW, Gray CF. Project management : the managerial proces. Maidenhead: McGraw-Hill 2011.

[4] Toor S-UR, Ogunlana SO. Beyond the 'iron triangle': Stakeholder perception of key performance indicators (KPIs) for large-scale public sector development projects. Int J Proj Manage 2010; 28: 228-36.

[5] Doloi HK. Understanding stakeholders' perspective of cost estimation in project management. Int J Proj Manage 2011; 29: 622-36.

[6] Lloyd-Walker B, Walker D. Authentic leadership for 21st century project delivery. Int J Proj Manage 2011; 29: 383-95.

[7] Shenhar A, Poli M, Lechner T. A new framework for strategic project management. In: Khalil TM, Lefebure LA, Mason RM, Eds. Management of Technology: The Key to Prosperty in the Third Millenium: London, Emerald Group Pub 2001.

[8] Briner W, Hastings C, Geddes M. Project leadership. Surrey, Gower 1996.

[9] Pinto JK. Project management : achieving competitive advantage. London: Pearson 2007.

[10] Kerzner H. Project management: A systems approach to planning, scheduling, and controlling. New Jersey: John Wiley \& Sons Inc. 2009.

[11] Thompson JL. Strategy in action. London: Chapman \& Hall 1995.

[12] Shenhar AJ, Dvir D, Levy O, Amaltz AC. Project success: A multidimensional strategic concept. Long Range Planning 2001; 34: 699-725.

[13] Wald PDA. Potentiale und Bedeutung des Projektmanagements aus der perspektive des topmanagements. Oestrich-Winkel: International University Schloß Reichartshausen: European Business School 2008.

[14] Velcu O. Strategic alignment of ERP implementation stages: An empirical investigation. Inform Manage 2010; 47: 158-66.

[15] Morris P, Jamieson A. Translating corporate strategy into project strategy: realizing corporate strategy through project management. Newtown Square, Project Management Institute, Inc. 2004.

[16] Shenhar AJ. Strategic Project Leadership: Toward a strategic approach to project management. R Manage 2004; 34: 569-578.

[17] Hersey P, Blanchard KH. Management of Organizational Behavior-Utilizing Human Resources. New Jersey: Prentice Hall 1977.

[18] Blanchard KH, Zigarmi P, Zigarmi D. Leadership and the one minute manager: Increasing effectiveness through situational leadership. New York: Morrow 1985.

[19] Bass BM. Transformational leadership: Industry, military, and educational impact. New Jersey: Erlbaum 1998.

[20] Avolio BJ, Bass BM. Developing potential across a full range of leadership: Cases on transactional and transformational leadership. Mahwah, NJ: Lawrence Erlbaum Associates 2002.

[21] Burke CS, Stagl KC, Cameron K, Goodwin GF, Salas E, Halpin SM. What type of leadership behaviours are functional in teams? A meta-analysis. Leadership Quart 2006; 17: 288-307. 
[22] Waldman D, Ramirez G, House R, Puranam P. Does leadership matter? CEO leadership attributes and profitability under conditions of perceived environmental uncertainty. Acad Manage J 2001; 44: 134-43.

[23] Chen J, Silverthorne C. Leadership effectiveness, leadership style and employee readiness. Leader Organ Dev J 2005; 26: 280-8.

[24] Shenhar AJ. Strategic Project Leadership: Toward a strategic approach to project management. R D Manage 2004; 34: 569-78.

[25] Kaulio MA. Project leadership in multi-project settings: Findings from a critical incident study. Int J Proj Manage 2008; 26: 338-47.

[26] Mumford MD, Scott GM, Gaddis B, Strange JM. Leading creative people: Orchestrating expertise and relationships. Leadership Quart 2002; 13: 705-50.

[27] Hotho S, Champion K. Small businesses in the new creative industries: innovation as a people management challenge. Manage Dec 2011; 49: 29-54.

[28] Townley B, Beech N, McKinlay A. Managing in the creative industries: Managing the motley crew. Hum Relat 2009; 62: 93962.

[29] Avolio BJ, Bass BM. Developing potential across a full range of leadership: Cases on transactional and transformational leadership. Mahwah, NJ: Lawrence Erlbaum Associates 2002.

[30] Amabile TM. A model of creativity and innovation in organizations. In: Staw BM, Cummings LL, Eds. Research in organizational Behavior. Greenwich, JAI Press 1988; pp. 123-67.
[31] Wang A-C, Cheng B-S. When does benevolent leadership lead to creativity? The moderating role of creative role identity and job autonomy. J Organ Behav 2010; 31: 106-21.

[32] Kaulio MA. Project leadership in multi-project settings: Findings from a critical incident study. Int J Proj Manage 2008; 26: 338-47.

[33] Salkind NJ. Exploring Research. New Jersey: Pearson Education Inc. 2009.

[34] Bryman A. Quantity and quality in social research, London: Routledge 1988

[35] Stake RE. The art of case study research. London: Sage Publications 1995.

[36] Robson C. Real World Research: A Resource for Social and Practitioner-Researchers. Oxford: Blackwell 2002.

[37] Yin RK. Case Study Research: Design and Methods. Thousand Oaks, Sage Publications Inc. 2003.

[38] European Commission. Small and medium-sized enterprises. Enterprise \& Industry: Available from: http://ec.europa.eu/enterpri se/policies/sme/facts-figures-analysis/sme-definition/index en.htm

[39] Miles M, Huberman M. Qualitative Data Analysis: An Expanded Sourcebook. Thousand Oaks, Sage Publications 1994.

[40] Wang A-C, Cheng B-S. When does benevolent leadership lead to creativity? The moderating role of creative role identity and job autonomy. J Organ Behav 2010; 31: 106-21

[41] Hotho S, Champion K. Small businesses in the new creative industries: innovation as a people management challenge. Manage Dec 2011; 49: 29-54.

(C) Galloway and Haniff; Licensee Bentham Open

This is an open access article licensed under the terms of the Creative Commons Attribution Non-Commercial License (http://creativecommons.org/licenses/bync/3.0/) which permits unrestricted, non-commercial use, distribution and reproduction in any medium, provided the work is properly cited. 